\title{
Heterogeneous Capital, Entrepreneurship, and Economic Organization
}

\author{
Kirsten Foss, Nicolai Foss \\ Department of Industrial Economics and Strategy \\ Copenhagen Business School \\ Peter G. Klein, Sandra K. Klein \\ Department of Economics, Terry College of Business \\ University of Georgia \\ 20 December 2001 \\ Prepared for the Israel Kirzner Festschrift, \\ Edited by Mario Rizzo \\ (Special Issue of Journal des Economistes et des Etudes Humaines)
}

JEL Classification: B20 B53 D2 


\section{Introduction}

Austrian economics is said to lack a distinct theory of the firm (Loasby 1991; Foss 1994; Witt 1999). Several recent writers have sensed an intellectual kinship between Austrian economics and the "capabilities" theory of the firm, an approach to economic organization that takes seriously the Hayekian notions of tacit, dispersed knowledge and rule-following behavior (Malmgren 1961; O'Driscoll and Rizzo 1985; Loasby 1991; Langlois 1992, 1995, 1998; Foss 1997, Foss and Christensen 2001; Dulbecco and Garrouste 1999). Exploring this theme has become a virtual cottage industry in recent years. However, the literature has produced few distinctive insights and refutable implications, and is instead largely limited to exploring similarities that exist between the two bodies of thought. We are concerned by what we see as a neglect of other important Austrian themes - particularly entrepreneurship and capital theory - in the recent literature on Austrian economics and the firm. ${ }^{1}$

Here we outline an Austrian approach to economic organization based on the entrepreneur and the Austrian idea of capital as heterogeneous and timedimensioned, two themes associated closely with Kirzner's (1966, 1973, 1997) contributions. Our unit of analysis is the capital asset. We start with the Austrian concept of heterogeneous capital and provide an economic interpretation of such heterogeneity. In our view, capital assets are heterogeneous to the extent that they possess various attributes, many of which may be unknown to the owners of these assets. Moreover, many attributes are costly to measure. These facts help explain a host of traditional and neglected issues in the theory of economic organization. In other words, the theory of the firm has much to gain from embracing Kirznerian ideas on entrepreneurship and capital heterogeneity.

Because entrepreneurs typically lack perfect knowledge of an asset's relevant attributes, it is usually the assets themselves, and not particular attributes, which are traded in capital markets. Ownership of an asset confers the (residual) right to exploit future, as yet undiscovered, attributes of that asset, and entrepreneurs may acquire assets precisely to be in a position to exploit these future attributes. This reason for acquiring ownership rights helps explain changes in firm boundaries through mergers, acquisitions, and divestitures: Entrepreneurs often must "try out" various capital assets, and combinations of assets, to gauge the value of these assets when used in production. We further argue that aspects of internal organization, such as the authority relation, can be understood as attempts to economize on the costs of experimenting with heterogeneous capital assets. In this sense, our approach also holds the key to a theory of the existence of the firm.

1 Exceptions are Dulbecco and Garrouste (1999) and Lewin (1998), who discuss capabilities ideas in the context of Austrian capital theory, and Witt (1999), who tries to integrate the entrepreneur and the theory of the firm. Klein (1999) emphasizes the relationship between entrepreneurship and firm boundaries. 


\section{Capital Heterogeneity}

\section{Austrian Capital Theory}

The concept of heterogeneous capital has a long and distinguished place in Austrian economics. ${ }^{2}$ The development of Austrian capital theory has been marked by the struggle to develop consistent analytical categories and aggregate measures for a class of goods that are fundamentally heterogeneous. In general, Austrian writers have moved away from relatively aggregate concepts emphasized by BöhmBawerk (1959) towards increasingly disaggregated ones that are more consistent with Austrian methodological individualism and subjectivism (Lewin 2000). A high point of this evolution is Kirzner's 1966 book, An Essay on Capital, which Garrison (1997: 511) calls "possibly the most underrated of all [Kirzner's] contributions."

Early Austrian writers recognized that capital has a time dimension as well as a value dimension. Menger (1871) characterized goods in terms of "orders": Goods of lowest order are those consumed directly; tools and machines used to produce those consumption goods are of a higher order; and those capital goods used to produce the tools and machines are of an even higher order. ${ }^{3}$ Building on his theory that the value of all goods is determined by their ability to satisfy consumer wants, Menger showed that the value of the higher-order goods is given ("imputed") by the value of the lower-order goods they produce. Moreover, because certain capital goods are themselves produced by other, higher-order capital goods, it follows that capital goods are not identical, at least by the time they are employed in the production process. This is not to say that there is no substitution among capital goods, but that the degree of substitution is limited; as Lachmann (1956) put it, capital goods are characterized by "multiple specificity." Some substitution is possible, but only at a cost.

Hayek's Prices and Production (1931) introduced the famous "Hayekian triangles" to illustrate the relationship between the value of capital goods and their place in the temporal sequence of production. Because production takes time, factors of production must be committed in the present for making final goods that will have value only in the future after they are sold. However, capital is heterogeneous. As capital goods are used in production, they are transformed from general-purpose materials and components to intermediate products specific to particular final goods. Consequently, these assets cannot be easily redeployed to alternative uses if demands for final goods change. The central macroeconomic problem in a modern capital-using economy is thus one of intertemporal coordination: how can the allocation of resources between capital and consumer goods be aligned with consumers' preferences between present and future consumption? In The Pure Theory of Capital (1941) Hayek describes how the economy's structure of production depends on the characteristics of capital goods-durability, complementarity, substitutability, specificity, and so on. This structure can be described by the various "investment

2 See Lewin (2000) for an overview.

3 Böhm-Bawerk (1959) used the term "maturity classes" for the same concept. 
periods" of inputs, an extension of Böhm-Bawerk's notion of "roundaboutness," the degree to which production uses resources over time. ${ }^{4}$

This understanding of capital as a complex structure formed the basis of the Mises-Hayek theory of the business cycle. Monetary injections, by lowering the rate of interest below its "natural rate," distort the economy's intertemporal structure of production. The reduction in interest rates caused by credit expansion directs resources toward capital-intensive processes and early stages of production (whose investment demands are more interest-rate elastic), thus "lengthening" the period of production. Investments in some stages of production are "malinvestments" if they do not help to align the structure of production to consumers' intertemporal preferences. The boom generated by the increase in investment is artificial; eventually, market participants come to realize that there are not enough savings to complete all the new projects, and the boom becomes a bust as these malinvestments are discovered and liquidated.

The concept of "malinvestment" is foreign to neoclassical production theory (as well as mainstream macroeconomics), which usually considers only the level of investment. Modern production theory focuses on a single stage of production in which "capital," along with other inputs, is transformed into final goods. In economics textbooks, the "firm" is a production function or production possibilities set, a "black box" that transforms inputs into outputs. Given the existing state of technology, the prices of inputs, and a demand schedule, the firm maximizes money profits subject to the constraint that its production plans must be technologically feasible. The legal boundary of the firm - defined in terms of the ownership of assets - is indeterminate in these models.

Kirzner's Essay on Capital (1966) provided an important refinement to the Austrian theory of capital by emphasizing the role of the entrepreneur the theme that dominates Kirzner's later work). ${ }^{5}$ Earlier Austrian writers, particularly BöhmBawerk, tried to characterize the economy's capital structure in terms of its physical attributes. Böhm-Bawerk attempted to describe the temporal "length" of the structure of production by a single number, the "average period of production." This attempt Böhm-Bawerk was sharply criticized by John Bates Clark (1893) and by Menger himself (who called Böhm-Bawerk's capital theory "one of the greatest errors ever committed" (Schumpeter 1954: 847n8)). Kirzner's approach avoids these difficulties by defining capital assets in terms of subjective, individual production plans, plans that are formulated and continually revised by profit-seeking entrepreneurs. Capital goods should thus be characterized, not by their physical properties, but by their place in the structure of production as conceived by entrepreneurs. The actual place of any capital good in the time sequence of production is given by the market for capital goods, in which entrepreneurs bid for factors of production in anticipation of future consumer demands. This subjectivist,

4 Hayek ultimately rejected Böhm-Bawerk's "average period of production" as a useful concept, though he had used it earlier in Prices and Production (1931) (see Hayek 1941).

5 See also the essays collected in Kirzner 1996. 
entrepreneurial approach to capital assets is particularly congenial to theories of the firm that focus on entrepreneurship and the ownership of assets.

\section{An "Attributes Approach" to Capital Heterogeneity}

Given the lengthy debates between the Austrian school (and within the Austrian school itself) on the problems of measuring a heterogeneous capital stock, it is surprising that relatively little analytical effort has been devoted to the concept of heterogeneity itself. The notion of heterogeneous capital is crucial not just for Austrian capital theory, but for (Austrian) economics in general. For example, economic calculation - the tool entrepreneurs use to align the economy's structure of production with consumer wants - would be severely limited in a world of homogenous capital. The entrepreneur's primary function is to choose among the various combinations of factors suitable for producing particular goods (and to decide whether these goods should be produced at all), based on current prices for the factors and expected future prices of the final goods. If capital is a single "good," with one price, then entrepreneurship is reduced to choosing between capitalintensive and labor-intensive production methods (or among types of labor). Lachmann (1956: 13, 16), by contrast, stressed that real-world entrepreneurship consists primarily of choosing among combinations of capital assets:

We are living in a world of unexpected change; hence capital combinations ... will be ever changing, will be dis-solved and re-formed. In this activity, we find the real function of the entrepreneur.

[T] he entrepreneur's function ... is to specify and make decisions on the concrete form the capital resources shall have. He specifies and modifies the layout of his plant ... As long as we disregard the heterogeneity of capital, the true function of the entrepreneur must also remain hidden.

Unfortunately, the implications of capital heterogeneity for entrepreneurship have received relatively little attention in the Austrian literature. Böhm-Bawerk's approach to capital theory, which tends to obscure heterogeneity among capital goods within given levels of the overall structure of production, focused attention on the characteristics of the aggregate capital stock. Hayek's (1941) more complex (and microeconomic) treatment has remained relatively obscure. Kirzner's subjectivist, entrepreneurial approach provides a convenient way to approach the problem of heterogeneity. Capital goods are not heterogeneous because of their objective characteristics, but because they play particular roles within the entrepreneur's overall production plan. In our interpretation, capital goods are distinguished by their attributes, in the terminology of Barzel (1997). ${ }^{6}$

Attributes are characteristics and possible uses of assets, as perceived by an entrepreneur. ${ }^{7}$ For example, a copying machine has multiple attributes in the sense

6 Foss and Foss $(2000,2002 \mathrm{a} \& b)$ explore the links between Austrian economics and Barzel's approach to the economics of property rights. See also Moss (1991) for thoughts on the complementarity between notions of property rights and Austrian economics.

7 In other words, they go beyond Lancasterian characteristics that are of a more objective character. 
that it can be used at different time, by different people, for different types of copying work, that it can be purchased in different colors, sizes, and so on. Clearly, virtually all assets have multiple attributes. Specificity and complementarity - key notions in both Austrian capital theory and modern theories of economic organization (Williamson 1985, 1996; Hart 1995) - are more abstract examples of attributes. In our terminology, capital assets are heterogeneous to the extent that they have different, and different levels of, valued attributes. Attributes may also vary over time, even for a particular asset. In a world of "true" uncertainty, entrepreneurs are unlikely to know all relevant attributes of all assets when production decisions are made. Nor can the future attributes of an asset, as it is used in production, be forecast with certainty. ${ }^{8}$ Future attributes must be discovered over time, as assets are used in production. Or, to formulate the problem slightly differently, future attributes are created as entrepreneurs envision new ways of using assets to produce consumer goods.

\section{Heterogeneous Assets, Property Rights, and Ownership}

Focusing on attributes not only helps illustrate the concept heterogeneous capital, but also illuminates the vast literature on property rights and ownership. Barzel (1997) stresses that property rights are held over attributes, ${ }^{9}$ and property rights to known attributes of assets are the relevant units of analysis in his work. In contrast, he dismisses the notion of asset ownership as essentially legal and extraeconomic. Similarly, Demsetz argues that the notion of "full private ownership" over assets is "vague," and "must always remain so," because "there is an infinity of potential rights of actions that can be owned ... It is impossible to describe the complete set of rights that are potentially ownable" (Demsetz 1988: 19).

However, as we noted above, most assets have unspecified, not-yet-discovered attributes, and an important function of entrepreneurship is to create or discover these attributes. Contrary to Demsetz, it is exactly this feature that creates a distinct role for asset ownership -- i.e., for acquiring legal title to a bundle of existing attributes as well as to future attributes. Specifically, ownership is a low-cost means of allocating the rights to attributes of assets that are created or discovered by the entrepreneur-owner. For instance, those who create or discover new knowledge have an incentive to use it directly because it is costly to transfer knowledge to others. In a well-functioning legal system, ownership of an asset normally implies that the courts will not interfere when an entrepreneur-owner captures the value of newly created or discovered attributes of an asset he owns. Consequently, the entrepreneur-owner can usually avoid costly negotiation with those who are affected his creation or

8 This sense of uncertainty links naturally with the notion of contractual incompleteness. We explore the implications of this idea below.

9 Barzel (1994: 394; emphasis in original) defines a property right as "an individual's net valuation, in expected terms, of the ability to directly consume the services of the asset, or to consume it indirectly through exchange. A key word is ability: The definition is concerned not with what people are legally entitled to do but with what they believe they can do." Thus, property rights are essentially defined in a subjectivist manner, in terms of expectations. 
discovery. This keeps the dissipation of value at bay. Of course, asset ownership itself provides a powerful incentive to create or discover new attributes, as ownership conveys the legally recognized (and at least partly enforced) right to the income of an asset, including the right to income from new attributes..$^{10}$

The idea of heterogeneous capital is thus a natural complement to the Austrian theory of entrepreneurship. Entrepreneurs who seek to create or discover new attributes of capital assets will want ownership titles to the relevant assets, both for speculative reasons and for reasons of economizing on transaction costs. These arguments provide room for entrepreneurship that goes beyond deploying a superior combination of capital assets with "given" attributes, acquiring the relevant assets, and deploying these to producing for a market: Entrepreneurship may also be a matter of experimenting with capital assets in an attempt to discover new valued attributed. Such experimental activity may take place in the context of trying out new combinations through the acquisition of or merger with another firms, or in the form of trying out new combinations of assets already under the control of the entrepreneur. The entrepreneur's success in experimenting with assets in this manner may depends on what Kirzner (1973) terms his "alertness," along with secondary factors such as transaction costs in the market for corporate control, internal transaction costs, the entrepreneur's control over the relevant assets, how much of the expected return from experimental activity that he can hope to appropriate, and so on. These latter factors are key determinants of economic organization in modern theories of the firm. This suggests that there may be fruitful complementarities between the theory of economic organization, which is essentially a theory about the arrangements of property titles that create an efficient employment of capital assets, and Austrian theories of capital heterogeneity and entrepreneurship. These themes are developed in the following section.

\section{Economic Organization and Capital Heterogeneity}

In this section we argue that the Kirznerian subjectivist view of capital and entrepreneurship is a natural and valuable complement to modern theories of economic organization. These theories focus on the efficient organization of heterogeneous assets, but do so in lieu of an explicit theory of (heterogeneous) capital and of the entrepreneur. The treatment of capital outlined in this paper can improve our understanding of the dynamics of economic organization, such as changes in the boundaries of firms. These dynamics are at least partly driven by entrepreneurial activity that aims at creating or discovering hitherto unknown attributes, and also by specific allocations of property rights and ownership that respond to this kind of entrepreneurial activity, leading to changes in the boundaries and internal

10 Moreover, ownership simplifies the process of entrepreneurial arbitrage (Kirzner 1973, 1997)and hence helps to close pockets of ignorance in the market-by allowing entrepreneurs to acquire, in one transaction, a bundle of rights to attributes (i.e., a distinct asset). This means that the parties need not engage in costly bargaining over many rights to single attributes. The dissipation of value is thus minimized. 
organization of firms. We begin by outlining some links between modern theories of economic organization and Austrian ideas on capital and entrepreneurship. We then show how these ideas lead to distinct and novel insights about business combinations and aspects of internal organization. The discussion in the next draws largely on the authors' previous work (Foss and Foss 2000a\&b, 2001, 2002a\&b; Klein 1999, 2000; Klein and Klein 2001a\&b).

\section{Austrian Capital Theory and the Theory of the Firm: The Role of Specific Investments}

In a world of homogenous capital - the "shmoo" of Solow-style growth models - economic organization would be relatively unimportant. All capital assets possess the same attributes, and thus the costs of inspecting, measuring, and monitoring the attributes of productive assets is trivial. Exchange markets for assets would be virtually devoid of transaction costs. A few basic contractual problems in particular, principal-agent conflicts over the supply of labor services - would remain, though workers would all use identical capital assets. However, it is hard to see what role ownership of capital assets would play in this world. If the costs of measuring and specifying attributes are low, entrepreneurs and factor owners could contract over attributes, and there would be little incentive to acquire ownership of assets themselves. Transactions involving such assets would be governed by complete, contingent contracts. ${ }^{11}$ Because contracts would substitute for ownership in a shmoo world, the boundaries of firms would be indeterminate (Hart 1995).

By contrast, all modern theories of the firm assume (often implicitly) that capital assets possess varying attributes, so that all assets are not equally valuable in all uses. Some theories also assume that it is impossible to write complete, contingent contracts specifying the most valuable uses of such assets in all possible states of the world (Williamson 1996; Hart 1995). Contractual incompleteness exposes owners of productive assets to certain risks. Primarily, if circumstances change unexpectedly, the original contracts governing the use of these assets may no longer be effective. The need to adapt to unforeseen contingencies constitutes an important cost of contracting; failure to adapt imposes what Williamson (1991a) calls "maladaptation costs."

The most-often-discussed example of maladaptation is the "holdup" problem associated with relationship-specific investments. ${ }^{12}$ Investment in such assets exposes

11 Admittedly, the costs of drafting contracts could still leave many contracts incomplete, but this would not provide room for ownership either, as possessing completely homogenous capital would not confer any bargaining power in a trading relationship.

12 The holdup problem is the best-known example of a contractual hazard. More generally, contractual difficulties can arise from several sources: (1) bilateral dependence; (2) weak property rights; (3) measurement difficulties; (4) intertemporal issues such as "disequilibrium contracting, real-time responsiveness, long latency, and strategic abuse"; and (5) weaknesses in the institutional environment (Williamson 1996: 14). Each can impose maladaptation costs. Foreseeing this possibility, agents seek to reduce the potential costs of maladaptation by matching the appropriate governance structure with the particular characteristics of the transaction. 
agents to a potential hazard: If circumstances change, their trading partners may try to expropriate the rents accruing to the specific assets. Suppose an upstream supplier tailors its equipment for a particular customer. After the equipment is in place, the customer may demand a lower price, knowing that the salvage value of the specialized equipment is lower than the net payment it offers. In turn, this creates an under investment problem: Anticipating the customer's behavior, the supplier will be unwilling to install the custom machinery without protection for such a contingency, even if the specialized technology would make the relationship more profitable for both sides.

One way to safeguard rents accruing to specific assets is vertical (or lateral) integration, where a merger eliminates any adversarial interests. Less extreme options include long-term contracts, partial ownership, or agreements for both parties to invest in offsetting relationship-specific investments. Overall, several governance structures may be employed. According to transaction cost theory (Williamson 1996; Hart 1995), parties tend to choose the governance structure that best controls the underinvestment problem, given the particulars of the relationship.

In this way, the theory of the firm may be considered the study of alternative institutions of governance. Its working hypothesis, as expressed by Williamson (1991b: 79), is that economic organization is mainly an effort to "align transactions, which differ in their attributes, with governance structures, which differ in their costs and competencies, in a discriminating (mainly, transaction cost economizing) way."

It is obvious that maladaptation costs largely disappear if all assets are equally valuable in all uses. Potential hold-up problems would still be a concern for owners of relationship-specific human capital and raw materials, but disagreements over the efficient use of capital goods would become irrelevant. The scope of entrepreneurial activity would also be severely reduced, since entrepreneurs would have no need to try out (or "discover," in Kirzner's parlance) the relevant attributes of capital assets.

Capital heterogeneity thus has two important implications for economic organization. First, because it is difficult, or perhaps even impossible, to specify all relevant attributes of an asset ex ante, ownership rights are assigned to assets, not their attributes. Ownership of an asset gives the owner the rights to exploit attributes unknown at the time ownership rights are conferred. Because firms are defined in terms of asset ownership, this entrepreneurial perspective helps explain the boundaries of the firm. Second, because attributes of assets are costly to measure, and often unknown even to their owners, entrepreneurs must often experiment with different combinations of capital goods. This explains why firm boundaries are constantly shifting over time. We pursue some implications of these overall ideas in the rest of this section. 


\section{Entrepreneurship, Experimentation and the Existence of the Firm ${ }^{14}$}

In the modern economics of organization, the costs of coordinating transactions in the economy are largely taken as given. In other words, the costs of organizing a particular transaction with particular characteristics (for example, the degree of asset specificity) are the same, not only across firms but also over time. The analyst then proceeds to study the allocation of transactions over alternative modes of economic organization. Often this takes a counterfactual form (particularly Hart 1995). From the perspective on heterogeneous capital that we have developed in this paper, the conventional approach is not entirely satisfactory. First, the entrepreneur need not take asset attributes such as temporal and site specificity as given, as data for the problem of determining efficient organization; rather, such attributes are created or discovered through experimentation with different combinations of heterogeneous capital assets. Second, the costs of coordinating heterogeneous capital assets in production may change over time as a consequence of establishing new attributes of capital assets. Third, the ability to create or discover new attributes may vary systematically across modes of economic organization. The modern economics of organization provides little insight into these problems because it takes technological knowledge as a datum, focusing exclusively on the choice between technologies characterized by different degrees of asset specificity (Langlois and Foss 1999).

As Hayek (1941) and Lachmann (1956) explained, capital heterogeneity is closely related to the coordination problem. Thus, in a world of shmoo, coordination of plans is relatively straightforward. In the real world of heterogeneous capital assets, production plans are much more difficult to coordinate. Neoclassical microtheory sidesteps these problems by focusing on production functions, which assume that the assets controlled by the firm are already in their best uses. More realistically, however, agents are unlikely to have full knowledge ex ante about, for example, the optimal sequence of tasks, even if these agents had perfect knowledge about the functional characteristics of the relevant (physical) assets. Strikingly, the problem of defining an optimal sequence of tasks in even relatively simple production systems may require more calculation capacity than is available in a supercomputer (Galloway 1996). ${ }^{15}$ Given that the relationships among assets are generally unknown ex ante, some experimentation is necessary. First, one must isolate the system boundaries, that is, where the relevant relationships among assets are most likely to be located. Second, the experimental process must be like a controlled experiment (or a sequence of such experiments) to isolate the system from outside disturbances. Third, there must be some sort of guidance for the experiment. This may take many forms, ranging from centrally provided instructions to

14 The reasoning in this section is described in greater detail in Foss and Foss (2000b).

15 Thus, in describing the problem of scheduling batches in a 5 stage production process, Galloway (1996) writes: "[t]he best schedule is the one which minimizes this idle time. Unfortunately, the only way to find the best schedule is by trial and error, and with 20 batches there are $1.8 \times 10^{18}$ possible schedules. This problem is too large even for modern computers, so a simplifying assumption is frequently used" (p.64). 
negotiated agreements to shared understandings of where in the system to begin experimenting, how to avoid overlapping experiments, how to revised the experiment in light of past results, and so on.

This description of experimental activity is not merely a heuristic model; it regularly takes place in manufacturing departments in connection with identifying errors, installing new equipment, fine-tuning existing equipment, fine-tuning routines, finding ways to adjust to new inputs or input qualities, and the like. In the present context, the central problem is how this experimental process is best organized. Does the need for experimentation explain the existence of the firm, or can such experimentation be organized efficiently through markets?

In a world of complete knowledge and zero transaction cost, all rights to all uses of all assets could be specified in contracts. By contrast, in a world of heterogeneous assets with attributes that are costly to measure and partly unforeseen, complete contracts cannot be drafted. In turn, the resulting incomplete contracting may necessitate organization within the firm, or managed coordination through the entrepreneur's central direction. If relationship-specific assets are involved, the holdup problem described above becomes a serious concern. (Asset specificity may itself be an outcome of an experimental process.) More specifically, as experimental activity provides information about how to optimize the system, assets will be increasingly specific in terms of time and location. Temporal and site specificity will tend to increase as assets become more efficiently coordinated. ${ }^{16}$ This provides one rationale for organizing the experiments inside firms, though not the only one. Firms may also be justified by problems associated with the dispersion of knowledge across agents. Production systems may exhibit multiple equilibria, so that it is not obvious how to coordinate on equilibria or even which equilibria are the most preferred ones.

In principle, one may imagine that an experimenting team hires an outside consultant that guides the experimental activity by giving advice on the sequence of actions and asset uses, initiating the experiments, drawing the appropriate conclusions from each experiments, determining how these conclusions should influence further experimentation, and so on. However, such an arrangement is likely to run into numerous bargaining costs, not the least because under market contracting, any team member may be able to veto the advice provided by the consultant. Succumbing to authority may be the cost effective way of organizing the experimental activity. "Authority" here means that the entrepreneur has the right to redefine and reallocate decision rights among team members, and the right to sanction team members who do not use their decision rights efficiently. By possessing these rights, entrepreneur-managers can conduct experiments without continuously having to renegotiate contracts, saves bargaining and drafting costs. Such an arrangement then provides a setting for carrying out "controlled" experiments in which the entrepreneur-manager only changes some aspects of tasks

16 For example, just-in-time production systems often lead to an increase in asset specificity. 
to trace the effects of some specific rearrangements of rights. Arranging property rights in this way is tantamount to forming a firm.

\section{Entrepreneurship, Experimentation, and the Boundaries of the Firm ${ }^{17}$}

The theory of firm boundaries is a relatively undeveloped area in the Austrian literature. Klein (1996) argues for a modified Coasian, or contractual, view of firm boundaries, in which the limits to organization are given by the need to perform economic calculation using prices generated in external markets. Other writers see the Austrian approach as more congenial to the resource-based theory of the firm, defining firms' capabilities in terms of Hayekian tacit knowledge (Langlois 1992; Minkler 1993). In either case, we can think of a merger or takeover as a response to a valuation discrepancy: Acquisition occurs when the value of an existing firm's assets is greater to an outside party than to its current owners. Put differently, merger can be a response to economies of scope, in that the value of the merging firms' assets combined exceeds their joint values separately.

New combinations of corporate assets can generate efficiencies by replacing poorly performing managers, creating operating synergies, or establishing internal capital markets. Like other business practices that do not conform to textbook models of competition, mergers, acquisitions, and financial restructurings have long been viewed with suspicion by some commentators and regulatory authorities. However, the academic literature clearly suggests that corporate restructurings do, on average, create value (Jarrell, Brickley, and Netter 1988; Andrade, Mitchell, and Stafford 2001). Given such benefits, why are many mergers later "reversed" in a divestiture, spinoff, or carve-out? Klein and Klein (2001a) distinguish between two basic views. The first, which may be termed empire building, holds that entrenched managers make acquisitions primarily to increase their own power, prestige or control, producing negligible efficiency gains, and that acquisitions by manager-controlled firms are likely to be divested ex post. Most important, because the acquiring firm's motives are suspect, such acquisitions are ex ante inefficient; neutral observers can predict, based on pre-merger characteristics, that these mergers are unlikely to be viable over time. (Moreover, by permitting these acquisitions, capital-market participants are also guilty of systematic error.)

A second view, which Klein and Klein (2001a) term entrepreneurial market process, acknowledges that unprofitable acquisitions may be "mistakes" ex post, but argues that poor long-term performance does not indicate ex ante inefficiency. In the market-process perspective, a divestiture of previously acquired assets may mean simply that profit-seeking entrepreneurs have updated their forecasts of future conditions or otherwise learned from experience. As Mises (1949: 252) puts it, "the outcome of action is always uncertain. Action is always speculation." Consequently, "the real entrepreneur is a speculator, a man eager to utilize his opinion about the future structure of the market for business operations promising profits. This specific

17 This section draws on material in Klein and Klein (2001a). 
anticipative understanding of the conditions of the uncertain future defies any rules and systematization" (p. 585, emphasis added).

Klein and Klein (2001a) discuss empirical evidence that the long-term success or failure of corporate acquisitions cannot, in general, be predicted by measures of manager control or principal-agent problems. However, significantly higher rates of divestiture tend to follow mergers that occur in a cluster of mergers in the same industry. As argued by Mitchell and Mulherin (1996), Andrade and Stafford (1999), and Andrade, Mitchell, and Stafford (2001), mergers frequently occur in industry clusters, suggesting that mergers are driven in part by industry-specific factors, such as regulatory shocks. When an industry is regulated, deregulated, or re-regulated, economic calculation becomes more difficult, and entrepreneurial activity is hampered. It should not be surprising that poor long-term performance is more likely under those conditions.

This notion of entrepreneurial decision-making under uncertainty squares with recent theories of acquisitions as a form of experimentation (Mosakowski 1997; Boot, Milbourn, and Thakor 1999; Matsusaka, 2001). In these models, profit-seeking entrepreneurs can learn their own capabilities only by trying various combinations of activities, which could include diversifying into new industries. Firms may thus make diversifying acquisitions even if they know these acquisitions are likely to be reversed in a divestiture. This process generates information that is useful for revising entrepreneurial plans, and thus an acquisition strategy may be successful even if individual acquisitions are not. In these cases, the long-term viability of an acquisition may be systematically related to publicly observable, pre-merger characteristics associated with experimentation, but not characteristics associated with managerial discretion.

\section{Conclusion}

Capital theory is a difficult subject, one "beset with many perplexities and ambiguities" (Garrison 1990: 133). Most of these difficulties involve aggregate measurement problems: How large is the economy's overall capital stock, and how "long" is the average period of production? A substantial body of literature in Austrian economics addresses these questions, especially as they relate to macroeconomic fluctuations. However, Austrian writers have paid relatively little attention to the microeconomic aspects of capital heterogeneity. We have argued that the Austrian theory of capital, particularly as developed by Kirzner (1966), has important implications for the theory for economic organization. Heterogeneous, time-dimensioned capital, "real" uncertainty, and entrepreneurship help explain the existence of firms and changes in the boundaries of firms. While some aspects of these ideas have been incorporated into contemporary theories of the firm, the full implications of Austrian capital theory have not yet been fully appreciated.

We are sympathetic to modern theories of economic organization, such as the transaction cost and incomplete contracts approaches, that also focus on asset 
ownership. However, as Demsetz (1991) points out, these approaches treat knowledge needed for production as essentially free, while knowledge needed for exchange is costly. Langlois and Foss (1999) further argue that transaction cost economics and the incomplete contracts theory of the firm are, on the production side, derived too closely from the neoclassical production-function setup with its attendant assumptions. Arguably, these theories do not take the idea of heterogeneous capital seriously enough.

Capabilities theories, by contrast, acknowledge that both production and transaction knowledge are costly. The Austrian theory that we have outlined in this paper clearly sides with the capabilities approach in this regard: if capital assets (including knowledge assets) are heterogeneous in sense outlined above, the knowledge needed for production should be costly to acquire. For this reason, firms do not possess the same "capabilities." Still, our approach to economic organization, which ties together heterogeneous assets, entrepreneurship, and transaction (measurement) costs, is more microeconomic than the usual capabilities approach. We are confident that further research along these lines will continue to be fruitful.

\section{References}

Alchian, Armen A. and Harold Demsetz. 1972. "Production, Information Costs, and Economic Organization," in Armen A. Alchian. 1977. Economic Forces at Work. Indianapolis: Liberty Press.

Andrade, Gregor, and Erik Stafford. 1999. "Investigating the Economic Role of Mergers." Working paper, Harvard Business School.

Andrade, Gregor, Mark Mitchell, and Erik Stafford. 2001. "New Evidence and Perspectives on Mergers." Journal of Economic Perspectives 15: 103-120.

Barzel, Yoram. 1994. "The Capture of Wealth by Monopolists and the Protection of Property Rights," International Review of Law and Economics: 393-409.

Barzel, Yoram. 1997. Economic Analysis of Property Rights. Cambridge: Cambridge University Press.

Böhm-Bawerk., Eugen von. 1959. Capital and Interest. 3 vols. Originally published in German in 1884, 1889, 1909. South Holland: Libertarian Press.

Boot, Arnoud W. A., Todd T. Milbourn, and Anjan V. Thakor. 1999. “Megamergers and Expanded Scope: Theories of Bank Size and Activity Diversity." Journal of Banking and Finance 23: 195-214.

Clark, John Bates. 1893. "The Genesis of Capital," Yale Review 2: 302-315.

Cowen, Tyler and David Parker. 1997. Markets in the Firm: A Market Process Approach to Management. London: The Institute of Economic Affairs.

Dulbecco, Philippe and Pierre Garrouste. 1999. "Towards an Austrian Theory of the Firm," Review of Austrian Economics 11: 43-64. 
Foss, Nicolai J. 1994. "The Theory of the Firm: The Austrians as Precursors and Critics of Contemporary Theory," Review of Austrian Economics 7: 31-64.

Foss, Nicolai J. 1997 "Austrian Insights and the Theory of the Firm”, Advances in Austrian Economics 4: 175-198.

Foss, Kirsten and Nicolai Foss. 2000a. "Theoretical Isolation in Contract Economics," Journal of Economic Methodology 7: 313-339.

Foss, Kirsten and Nicolai Foss. 2000b. "Learning in Firms: Knowledge-Based and Property Rights Perspectives," European Journal of Social and Economic Systems 14: 119-142.

Foss, Kirsten and Nicolai Foss. 2001. "Assets, Attributes, and Ownership," International Journal of the Economics of Business 8: 19-37.

Foss, Kirsten and Nicolai Foss. 2002a. "Organizing Economic Experiments: the Role of Firms," forthcoming in Review of Austrian Economics.

Foss, Kirsten and Nicolai Foss. 2002b. “Economic Organization and Productive and Destructive Entrepreneurship," in Foss, Nicolai and Peter G. Klein, eds. 2002. Entrepreneurship and The Firm: Austrian Perspectives on Economic Organization. Aldershott, U.K.: Edward Elgar.

Galloway, Les. 1996. Operation Management: The Basics. London: International Thomson Business Press.

Garrison, Roger W. 1990. “Austrian Capital Theory: The Early Controversies," History of Political Economy 22 (supplement): 133-154.

Garrison, Roger W. 1997. Review of Kirzner, Essays on Capital and Interest, in The Freeman 47: 511-513.

Hart, Oliver and John Moore. 1990. "Property Rights and the Nature of the Firm," Journal of Political Economy 98: 1119-1158.

Hart, Oliver. 1995. Firms, Contracts, and Financial Structure. Oxford: Oxford University Press.

Hayek, F. A. 1931. Prices and Production. London: George Routledge \& Sons.

Hayek, F. A. 1941. The Pure Theory of Capital. London: George Routledge \& Sons.

Holmström, Bengt and Paul Milgrom. 1991. “Multitask Principal-Agent Analysis: Incentive Contracts, Asset Ownership and Job Design," Journal of Law, Economics and Organization 7: 24-54.

Ionnanides, Stavros. 1999. "Towards an Austrian Perspective on the Firm," Review of Austrian Economics 11: 77-98.

Jarrell, Gregg A., James A. Brickley, and Jeffry M. Netter. 1988. "The Market for Corporate Control: The Empirical Evidence since 1980," Journal of Economic Perspectives 2: 49-68.

Kirzner, Israel M. 1966. An Essay on Capital, New York: Augustus M. Kelley. 
Kirzner, Israel M. 1973. Competition and Entrepreneurship. Chicago: University of Chicago Press.

Kirzner, Israel M. 1996. Essays on Capital and Interest: An Austrian Perspective. Brookfield, MA: Edward Elgar.

Kirzner, Israel M. 1997. "Entrepreneurial Discovery and the Competitive Market Process: An Austrian Approach," Journal of Economic Literature 35: 60-85.

Klein, Peter G. 1996. "Economic Calculation and the Limits of Organization," Review of Austrian Economics 9: 3-28.

Klein, Peter G. 1999. "Entrepreneurship and Corporate Governance," Quarterly Journal of Austrian Economics 2: 19-42.

Klein, Peter G. 2000. “New Institutional Economics," in Boudewin Bouckeart and Gerrit De Geest, eds., Encyclopedia of Law and Economics (Cheltenham, U.K.: Edward Elgar): 456-489.

Klein, Peter G. and Sandra K. Klein. 2001a. “Do Entrepreneurs Make Predictable Mistakes? Evidence from Corporate Divestitures," Quarterly Journal of Austrian Economics 4: 3-25.

Klein, Peter G. and Sandra K. Klein. 2001b. "Are Divestitures Predictable? A Duration Analysis." Working paper, Department of Economics, University of Georgia.

Lachmann, Ludwig M. 1956. Capital and Its Structure. 1978 edition. Kansas City: Sheed Andrews and McNeil.

Langlois, Richard N. 1992. “Orders and Organizations: Toward an Austrian Theory of Social Institutions," in Bruce Caldwell and Stephan Boehm, eds. 1992. Austrian Economics: Tensions and New Directions, Boston: Kluwer.

Langlois, Richard N. 1995. "Do Firms Plan?" Constitutional Political Economy 6: 247261.

Langlois, Richard N. 1998. "Capabilities and the Theory of the Firm," in Nicolai J. Foss and Brian J. Loasby, eds. 1998. Capabilities, Coordination, and Economic Organization: Essays in Honor of George B Richardson. London: Routledge.

Langlois, Richard N. and Nicolai J. Foss. 1999. "Capabilities and Governance: the Rebirth of Production in the Theory of Economic Organization," Kyklos 52: 201218.

Lewin, Peter. 1998. "Capital Structure and Organizational Structure: an Austrian Market-Process Theory of the Firm," Working paper, School of Management, University of Texas, Dallas.

Lewin, Peter. 2000. Capital in Disequilibrium. London: Routledge.

Loasby, Brian J. 1991. Economics and Evolution. Manchester: Manchester University Press. 
Malmgren, H.B. 1961. "Information, Expectations, and the Theory of the Firm," Quarterly Journal of Economics 75: 399-421.

Matsusaka, John G. 2001. “Corporate Diversification, Value Maximization, and Organizational Capabilities," Journal of Business 74: 409-431.

Menger, Carl. 1871. Principles of Economics. 1985 edition. New York: New York University Press.

Minkler, Alanson P. 1993. “The Problem with Dispersed Knowledge: Firms in Theory and Practice," Kyklos 46: 569-87.

Mises, Ludwig von. 1949. Human Action. New Haven: Yale University Press.

Mitchell, Mark, and J. Harold Mulherin. 1996. "The Impact of Industry Shocks on Takeover and Restructuring Activity." Journal of Financial Economics 41: 193-229.

Mosakowski, Elaine. 1997. "Strategy Making Under Causal Ambiguity: Conceptual Issues and Empirical Evidence." Organization Science 8: 414-142.

Moss, Laurence. 1991. "The Chicago Intellectual Property Rights Tradition and the Reconciliation of Coase and Hayek," Eastern Economic Journal 17: 145-156.

Schumpeter, Joseph A. 1954. History of Economic Analysis. London: George Allen \& Unwin.

Williamson, Oliver E. 1985. The Economic Institutions of Capitalism. New York: Free Press.

Williamson, Oliver E. 1991a. "Comparative Economic Organization: The Analysis of Discrete Structural Alternatives," Administrative Science Quarterly 36: 269-96.

Williamson, Oliver E. 1991b. "Strategizing, Economizing, and Economic Organization," Strategic Management Journal 23: 75-94.

Williamson, Oliver E. 1996. The Mechanisms of Governance. Oxford: Oxford University Press.

Witt, Ulrich. 1999. "Do Entrepreneurs Need Firms? A Contribution to a Missing Chapter in Austrian Economics," Review of Austrian Economics 11: 99-110. 